\title{
Can the Pinus sylvestris var. mongolica sand-fixing forest develop sustainably in a semi-arid region?
}

\author{
Yiben Cheng ${ }^{1,2}$, Hongbin Zhan $^{3}$, Mingchang Shi ${ }^{1}$ \\ ${ }^{1}$ School of soil and water conservation, Beijing Forestry University, Beijing, China, 100083 \\ $5 \quad{ }^{2}$ Forest Ecosystem Studies, National Observation and Research Station, Jixian, Shanxi, China, 042200 \\ ${ }^{3}$ Department of Geophysical, Texas A\&M University in College Station, Texas, USA, 77840 \\ Correspondence to: Yiben Cheng (chengyiben07@gmail.com)
}

10 Abstract: Desertification is a global environmental and societal concern at present, and China is one of the countries that face the most severe damage of desertification. China's so-called Three North shelterbelt Program (3NSP) has produced a vast area of lined forest in the semi-arid regions with the purpose of battling desertification. Such a windbreaking and sand-fixing forest has successfully slowed down the incursion of desert. However, the vast artificial forestry consumes a large amount of water resources, which profoundly affect the fragile ecological environment in the semi-arid regions. In turn, a large amount of water loss also causes a great number of vegetation deaths or defects. To understand the water balance and sustainable development of artificial forest in semi-arid region, this study uses the 30-year-old lined Pinus sylvestris var. mongolica sand-fixing forest in the eastern part of Mu Us Sandy land in Northwestern China as an example. Specifically, this investigation studies the redistribution of water in soil under existing precipitation conditions, so as to evaluate whether the rain-feed forestry can develop sustainably or not. Rain gauge, newly designed lysimeter and soil moisture sensor are used to monitor precipitation, deep soil recharge (DSR) and soil water content, resulting in an accurate estimation of annual moisture distribution of the rain-feed Pinus sylvestris var. mongolica. The study shows that there are two obvious moisture recharge processes in an annual base for the Pinus sylvestris var. mongolica forest soil in Mu Us Sandy land: 1) the snow melted water infiltration-recharge process in the spring, and 2) the precipitation-recharge process in the summer. The recharge depth of the first process is $160 \mathrm{~cm}$. The second process results in DSR (referring to recharge that can reach a depth more than $200 \mathrm{~cm}$ and may eventually replenish the groundwater reservoir). The DSR of 2016-2018 is $1.4 \mathrm{~mm}, 0.2 \mathrm{~mm}, 1.2 \mathrm{~mm}$, respectively. To reach the recharge depths of $20 \mathrm{~cm}, 40 \mathrm{~cm}, 80 \mathrm{~cm}, 120 \mathrm{~cm}, 160 \mathrm{~cm}$, and $200 \mathrm{~cm}$, the corresponding precipitation intensities have to be $2.6 \mathrm{~mm} / \mathrm{d}, 3.2 \mathrm{~mm} / \mathrm{d}, 3.4 \mathrm{~mm} / \mathrm{d}, 8.2 \mathrm{~mm} / \mathrm{d}, 8.2 \mathrm{~mm} / \mathrm{d}$, and $13.2 \mathrm{~mm} / \mathrm{d}$, respectively. The annual evaporation amount in the Mu Us Sandyland Pinus sylvestris var. mongolica forest is $426.96 \mathrm{~mm}$ in 2016, $324.6 \mathrm{~mm}$ in $2017,416.253 \mathrm{~mm}$ in 2018 . This study concludes that under the current precipitation conditions, very small but observable DSR happened, thus the groundwater system underneath the forest may be replenished, meaning that the artificial Pinus forestry can probably develop sustainably. This study confirms that developing limited amount forestry in semi-arid regions is likely in a sustainable fashion. The widely variable annual precipitation in semi-arid areas may affect this conclusion and should be investigated in the future. 
Keywords: Pinus sylvestris var. Mongolia, Infiltration, Semi-arid region, Afforestation, Desertification control

\section{Introduction}

Desertification is a global threat that impacts heavily on the livelihoods of millions of people inside and outside the desert land (Yang et al., 2005). The true cost of desertification is frequently underestimated due to the unknown scale of these external and downstream impacts (Cao et al., 2011). Sand and dust storms happen when strong winds impact the arid and semi-arid regions (Sun et al., 2015;Wang et al., 2010a). Sandstorms occur relatively close to the ground and can rise to kilometers high into the atmosphere and transport very long distances (Wu et al., 2013). Sandstorms impact human health, agriculture and transport (Wang et al., 2013). Agroforestry is a proven approach to battle desertification or even eradicate sandstorms in some areas, but agroforestry taxes heavily on water resources in arid and semi-arid regions, which may cause other unwanted environmental problems (García Chevesich et al., 2017).

Soil moisture is a vital component in the ecological environment and is the source of life for plants on the earth surface (Sharma and Sharma, 2005). On the land surface of the Earth, not only the natural vegetation distribution is limited by water supply, but also the production of artificial vegetation relies on water supply more than any other factors (Gerten et al., 2004;Contreras et al., 2011). Therefore, the dynamic relations among soil, vegetation and soil moisture and the study on their regulation mechanism are of great concern in various disciplines like forestry, agriculture, livestock, and environment (Young, 1989; Li et al., 2013b). For instance, the research in this field in China in the past decade has deeply influenced the economic development strategies of arid and semi-arid regions (Cao et al., 2011), and lessons learnt can be applicable for management of arid and semi-arid regions in other parts of the World as well.

Semi-arid regions are transitional zones between arid-regions and humid-regions, and are also active areas where desertification takes place (Gong et al., 2004; Rhee et al., 2010). A semi-arid region generally refers to an area with a drought index (annual evaporation/annual precipitation) between 1.5 and 3.49. A region with less than $200 \mathrm{~mm}$ annual precipitation is often designated as an arid region (Su et al., 2007). A region with an annual precipitation between 200 $\mathrm{mm}$ and $500 \mathrm{~mm}$ is designated as a semi-arid region (Barton et al., 2008). The total arid and semi-arid area of the world is approximately 48 million $\mathrm{km}^{2}$, which is a third of the entire continental area of the World, covering more than 50 counties and regions (Gao et al., 2014). The vast arid, semi-arid, and semi-humid and drought-prone areas, are the birthplace of the world's ancient civilizations, and have an important place in the modern farming and livestock production industries (Ngigi et al., 2005). In the United States alone, 17 states in the West, which are mainly of arid and semi-arid climate, provide more than $80 \%$ of the farming and livestock products for the country (Powell et al., 1879). The former U.S.S.R. Central Asian arid and semi-arid regions provide $45 \%$ of the total commodity food for the former U.S.S.R (Bouwman et al., 2005; Kraemer et al., 2015). The farming and livestock products from the Central and Western Australian arid and semi-arid regions play an important role in the world market as well (Fagg and Stewart, 1994). 
China is one of the major arid countries in the world, with a total arid area of 2.8 million $\mathrm{km}^{2}$ (Wang et al., 2002), and a total semi-arid and semi-humid and drought-prone areas of 2.13 million $\mathrm{km}^{2}$ (Wang et al., 2004). These areas are mainly located to the north of the Kunlun Mountains-Qinling-Huai River line, starting from the northwestern border between China and Russia, all the way to the western foot of Daxinganling. The areas cover 965 counties in 16 provinces, municipalities, and autonomous regions (Su et al., 2007). This is more than half of the total land territory of China. In these areas, there are 55 million Acre arable land, which are 51\% of the total arable land of China. $65 \%$ of these areas are arid land without irrigation conditions (Boserup, 2011). Especially in the vast areas along the Great Wall to the east of Baotou, Inner Mongolia, and in the Loess Plateau, 99.7\% of the arable land are arid land. 83\% of the arid and semi-arid areas in China are concentrated in the northwest (Ma et al., 2008). Therefore, drought is the typical climate characteristic and a natural concern in the northwest regions of China.

To control desertification in the northwest regions, China launched a so-called Three North Forest Program (3NSP) in 1978 (Wang et al., 2010b), a large-scale reforestation program in the Northeast, Northwest, and North China. At the end of the $20^{\text {th }}$ century, the arid area in China expanded approximately $10,400 \mathrm{~km}^{2}$ per year. Such a rapid expansion of arid area has been halted since the beginning of $21^{\text {th }}$ century, partially thanks to the success of 3 NSP. Nowadays, the trend of arid area expansion in China has been reversed and the arid area decreases $2424 \mathrm{~km}^{2}$ annually. The sandy land (which is one of the most important types of arid area) in China used to expand $3436 \mathrm{~km}^{2}$ annually at the end of the $20^{\text {th }}$ century, and now it decreases $1980 \mathrm{~km}^{2}$ annually (Wenhua, 2004;Jiao et al., 2012). Studies have shown that China has made great achievements in sand prevention and control. China and India have contributed one-third of the world's new vegetation coverage. $42 \%$ of China's new vegetation coverage area is forest, and $32 \%$ is agricultural land. The expansion of green areas in India is mainly due to the expansion of agricultural land (82\%), and the contribution of forests is smaller than that in China (4.4\%) (Bawa et al., 2010;Menon et al., 2002). However, even with such an extraordinary achievement, there are still grave concerns in managing windbreak and sand-fixation forests (Wang et al., 2010a;Cao et al., 2011;Wang et al., 2010b). For example, reforestation is not successful in some places with unclear reasons. Specifically, trees grow into dwarf trees, which are ineffective in battling desertification, or even die.

Pinus sylvestris var. mongolica is a geographical variant of European red pine in the Far East (Bao, 2015;Li et al., 2004). It is naturally distributed in large areas of China's humid and semi-humid areas, especially Daxinganling in the northeast. It inherits the original European red pine's adaptive ability to a variety of ecological environments, and has characteristics such as heliophile, drought-resistant, cold-resistant, and soil infertility-resistant. It is one of the most common species used in 3NSP (Zhu et al., 2006). Since the start of 3NSP in 1978, Pinus sylvestris var. mongolica has been introduced and planted on a large scale in the windy and sandy areas in the Northeast, Northwest, and North China (Runnström, 2000). Up to present, it has been applied in more than 300 counties across 13 provinces, municipalities and autonomous regions, with a total area over $3 * 10^{5} \mathrm{hm}^{2}$ (Hu et al., 2008).

Now the question becomes: Is the reforestation of Pinus sylvestris var. mongolica in battling desertification in semi-arid regions of China sustainable? We will try to answer this question from a hydrological point of view by inspecting the relationship of precipitation, soil moisture change, and deep soil recharge (DSR) (referring to recharge that can reach a depth more than $200 \mathrm{~cm}$ and may eventually replenish the groundwater reservoir). In particularly, if 
a sizable DSR can occur, meaning that groundwater may be recharged from precipitation, the sustainable reforestation in the region is possible. To accomplish this goal, this study uses a newly developed DSR lysimeter to monitor a 30year old pine artificial forest in the Northwest China. The collected dataset is used to understand the soil moisture dynamic and the DSR of the Pinus sylvestris var. mongolica in sandy land. Specifically, we try to tackle the following issues: 1) Sources of soil water recharge in semi-arid areas, especially the source of deep soil layer moisture; 2) The precipitation density that causes infiltration and its maximal penetrating depth; 3) The rate of annual precipitation infiltration; 4) The evaporation amount of the pine forestry land. The ultimate goal is to find out whether the rain-feed Pinus sylvestris var. mongolica sand-fixing forest can develop sustainably or not in the study site.

\section{Material and Method}

\subsection{Overview of the study area}

The area under study is located in Chagan Naoer, on the northeastern edge of Mu Us Sandy land $\left(39^{\circ} 05^{\prime} 16.2^{\prime \prime} \mathrm{N}\right.$, $109^{\circ} 36^{\prime} 04^{\prime \prime}$ ), as shown in Figure 1. Mu Us Sandy land mainly consists of semi-fixed and fixed sand dunes, adjacent with the Loess Plateau, located in a desert-loess transitional zone. It has northwestern wind in the winter with a typically dry winter climate and frequent sandstorm. It has southeastern monsoon in the summer. The summer climate is relatively humid, and it is easy to form local heavy precipitation. The multi-year average precipitation is $400 \mathrm{~mm}$, mostly concentrated during the summer. The groundwater table depth varies between $2 \mathrm{~m}$ to $17 \mathrm{~m}$ in Mu Us Sandyland, and it is $8 \mathrm{~m}$ at the experimental area of this study (Runnström, 2003). The groundwater table is lower in the summer and higher in the spring, with a variation less than $1.5 \mathrm{~m}$. Since the initiation of 3NSP at Mu Us Sandy land in 1989, Pinus sylvestris var. mongolica has been planted in lines in the experimental area, with a $10 \mathrm{~m}$ line spacing, an average plant height of $6 \mathrm{~m}$, and an average crown diameter of $6.6 \mathrm{~m}$. The seasonal frozen soil period in the experimental area is from January to April, and from November to December in an annual base (Li et al., 2013a).
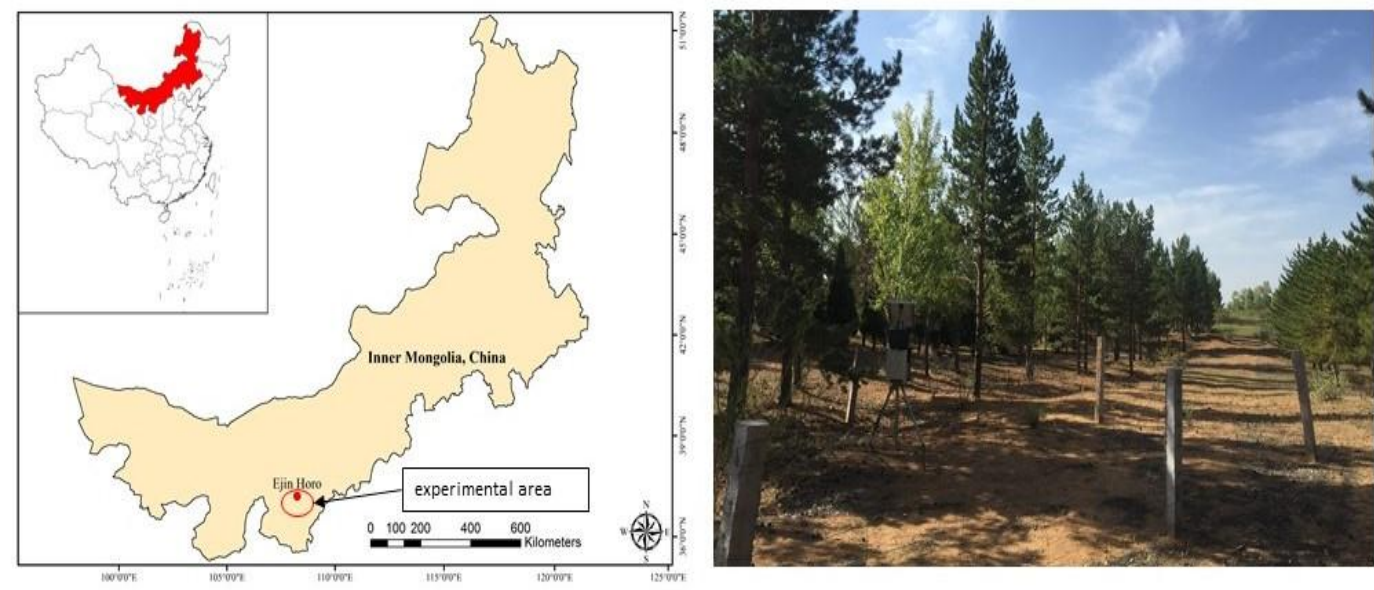

Figure 1. Geographic location of the experimental area and study site. 


\subsection{Experimental design}

Root analysis of Pinus sylvestris var. mongolica shows that it has a shallow root distribution and underdeveloped main root, which belongs to a typical lateral root type. The 30-year-old Pinus sylvestris var. mongolica's root distribution can reach $6.5 \mathrm{~m}$, with a concentrated area of $2.5 \mathrm{~m}$. In this study site, the ground water level is too deep to supply for roots, so Pinus sylvestris var. mongolica root is mostly distributed over a vertical range of $0-0.5 \mathrm{~m}$ and relies on precipitation for water supply. The original main root usually stops growing at 1.5-2 m depth (Zhu et al., 2006). Therefore, in the experimental design of this study, the lowest soil moisture sensor is placed at a depth of 200 $\mathrm{cm}$, and the lysimeter placement is also at the $200 \mathrm{~cm}$ depth. The canopy of Pinus sylvestris var. mongolica is capable of intercepting precipitation, thus affects the measurements of precipitation and soil moisture directly underneath the canopy (Roth et al., 2007). Therefore, the measurements of this study are made in the middle between the forest lines, without the interference of canopy.

\subsubsection{Soil moisture monitoring}

Based on the root depth of Pinus sylvestris var. mongolica, the depth range of soil moisture sensor placement is determined. A soil section is cut out in the middle between two forest lines. The section consists of a layer of dead tree leaves, a leached layer, a depositional layer, and a native soil layer, which is of fine sand. Soil moisture sensors (MiniTRASE TDR, USA) are placed in soil layers at $20 \mathrm{~cm}, 40 \mathrm{~cm}, 80 \mathrm{~cm}, 120 \mathrm{~cm}, 160 \mathrm{~cm}$, and $200 \mathrm{~cm}$ depths. The measurement interval is one hour.

\subsubsection{DSR monitoring}

To study the moisture distribution of Pinus sylvestris var. mongolica in Mu Us Sandy land, two sets of data need to be collected: precipitation from a rain gauge, and DSR measurement from a lysimeter. Surface runoff does not exist in the experimental area, thus is not a concern. Precipitation is monitored by rain gauge (Spectrum, USA, accuracy $0.2 \mathrm{~mm}$ ), placed $1.5 \mathrm{~m}$ above ground surface. This study uses a new lysimeter to measure the DSR (Cheng et al., 2017). Such a new lysimeter has two parts: an upper water balance part and a lower measurement part. As shown in Figure 2 , the water balance part uses a cylindrical impermeable side wall to enclose a soil column for measurement. The length of soil column is determined based by the capillary rise, which is approximately $60 \mathrm{~cm}$, based on the soil particle size distribution at the site. The advantage of this design is that when soil at point B in Figure 2 reaches saturation, the capillary water reaches point A. Therefore, when infiltrated water enters the water balance part at depth $\mathrm{A}$, additional infiltrated water after satisfying the saturation of soil between $\mathrm{A}$ and $\mathrm{B}$ will go into the measuring part. The measurement part has a measurement accuracy of $2 \mathrm{~mm}$ (Spectrum, USA). The lysimeter is placed at $200 \mathrm{~cm}$ depth to measure DSR, meaning that any precipitation-induced infiltration passing the $200 \mathrm{~cm}$ depth will not be subject to evaportranspirative process anymore. In another word, the infiltrated water that can pass the $200 \mathrm{~cm}$ depth of soil will keep going down and may become groundwater recharge. 
Before taking the measurements, the new lysimeter needs to be placed one year in advance, going through naturally settlement for a year, and allowing the soil to reach its pre-installation condition.

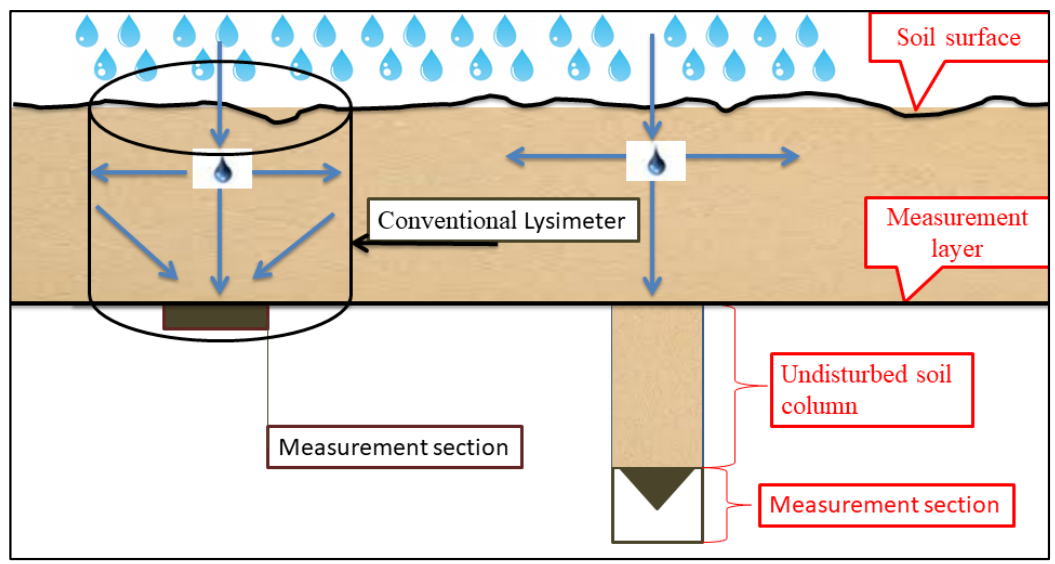

Figure 2. The schematic plot of a new lysimeter (on the right) with respect to the conventional lysimeter (on the left).

\section{Results and Discussion}

The soil moisture variation of Pinus sylvestris var. mongolica in 2016 is shown in Figure 3. It reveals that soil moisture has obvious seasonal variational trends. The soil from January to March is frozen. The near surface soil moisture recharge is from snowmelt. When the near surface frozen soil starts to thaw, soil at the $20 \mathrm{~cm}$ depth is recharged on February $9^{\text {th }}, 16^{\text {th }}$ and $26^{\text {th }}$ in 2016 . Soil at depths greater than $20 \mathrm{~cm}$ remains relatively stable. Frequent precipitation events usually occur from June to November, during which soil moisture changes considerably, and soil moistures at different depths exhibit periodic increase or decrease, regulated by the interplay of precipitation and evapotranspiration. After February $26^{\text {th }}$ in 2016 , soil gradually thaws completely. Figure 3 shows that snowmelt can recharge the soil moisture as deep as $140 \mathrm{~cm}$. The soil moisture at $200 \mathrm{~cm}$ depth is recharged for the first time after a heavy precipitation event on July $8^{\text {th }}$ in 2016. 
Hydrol. Earth Syst. Sci. Discuss., https://doi.org/10.5194/hess-2019-110

Manuscript under review for journal Hydrol. Earth Syst. Sci.

Discussion started: 18 March 2019

(c) Author(s) 2019. CC BY 4.0 License.
Hydrology and

Earth System

Sciences

Discussions

(c) (i)

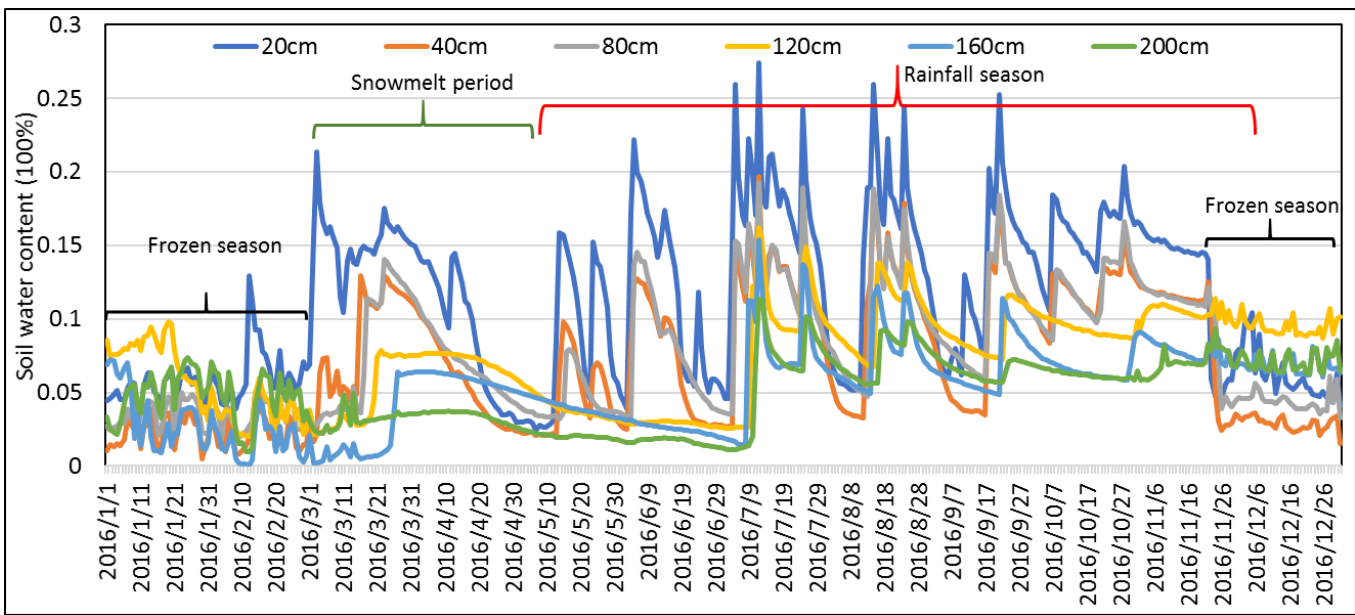

175

Figure 3. Annual precipitation and soil moisture of each layers in 2016.

In order to study the degree of soil moisture response to precipitation in individual layers, this research choose each layer's soil moisture at the beginning of each month as a representative, to observe whether the soil moisture in a specific layer is recharged. Figure 4 shows the soil moistures at depths of $20 \mathrm{~cm}, 40 \mathrm{~cm}, 80 \mathrm{~cm}, 120 \mathrm{~cm}, 160 \mathrm{~cm}$, and $200 \mathrm{~cm}$ at the beginning of each month. From Figure 3, the soil of Pinus sylvestris var. mongolica exhibits four distinctive layers: an evaporation layer at 0-40 cm depth, a lateral root activity layer at 40-160 cm depth, a dry soil layer at 160-200 cm depth, and a deep soil layer below $200 \mathrm{~cm}$. For the $0-40 \mathrm{~cm}$ evaporation layer, the soil moisture increases only under the effect of precipitation or snowmelt. Its moisture content decreases rapidly under the interplay of evaporation and infiltration. For the $40-160 \mathrm{~cm}$ root activity layer, the soil moisture is recharged from infiltrated water passing through the upper layer, and it gradually decreases under the effects of infiltration and root moisture absorption. For the 160-200 cm dry soil, the infiltrated water hardly reaches this layer, and the soil layer with a soil moisture under the withered point is formed. The deep soil below $200 \mathrm{~cm}$ depth is of native sand soil, and Figure 3 shows that the soil moisture content of this layer is recharged four times under heavy precipitation events in 2016. 


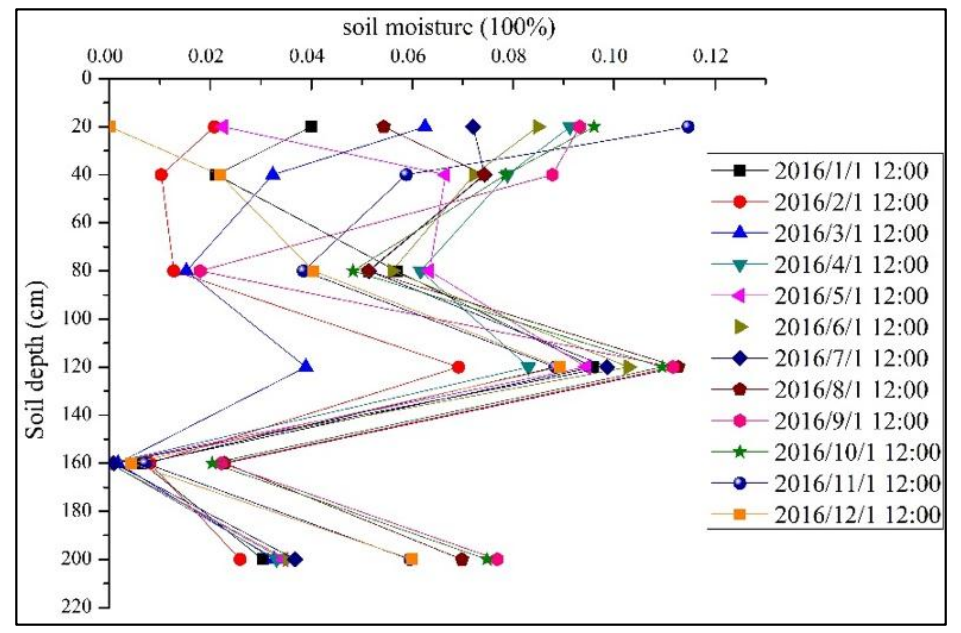

Figure 4. Month soil moisture changes of every soil layers.

The total precipitation in 2017 is $309 \mathrm{~mm}$, which was a dry year. There are 32 times observed precipitation in the whole year. The maximum precipitation intensity mount is $22 \mathrm{~mm} / \mathrm{d}$, in July 22, 2017. The soil moisture fluctuation in 2017 is similar to that in 2016. There is a freezing period from January-March, the surface soil freezes, and the soil water content changes in each soil layers are relatively stable. March to April belongs to the freezing and thawing mixed period, frozen water in the soil layer gradually melts, especially the surface layer frozen water functions as a reservoir. The frozen water replenishes the soil moisture of each soil layer; from April to November, it belongs to the soil water active period of the rainy season. Under the combined action of precipitation recharge, soil evapotranspiration and vegetation consumption, the soil moisture fluctuates rapidly; then the soil begins to freeze again in December. As shown in Figure 5, the soil moisture fluctuations intensely in the soil layers at $20 \mathrm{~cm}, 40 \mathrm{~cm}$, and $80 \mathrm{~cm}$ depths. The soil layer from $120 \mathrm{~cm}$ to $200 \mathrm{~cm}$ is relatively stable, and it is only replenished by freeze-thaw soil moisture during the freezing and thawing period (March to April). The $120 \mathrm{~cm}$ depth soil layer is replenished with water during the continuous summer precipitation process (on 14 October). The annual soil moisture infiltration is only $0.2 \mathrm{~mm}$, which is $1.2 \mathrm{~mm}$ lower than that of 2016. The lack of precipitation in 2017 causes a sharp drop in deep soil moisture infiltration. 
Hydrol. Earth Syst. Sci. Discuss., https://doi.org/10.5194/hess-2019-110

Manuscript under review for journal Hydrol. Earth Syst. Sci.

Discussion started: 18 March 2019

(c) Author(s) 2019. CC BY 4.0 License.

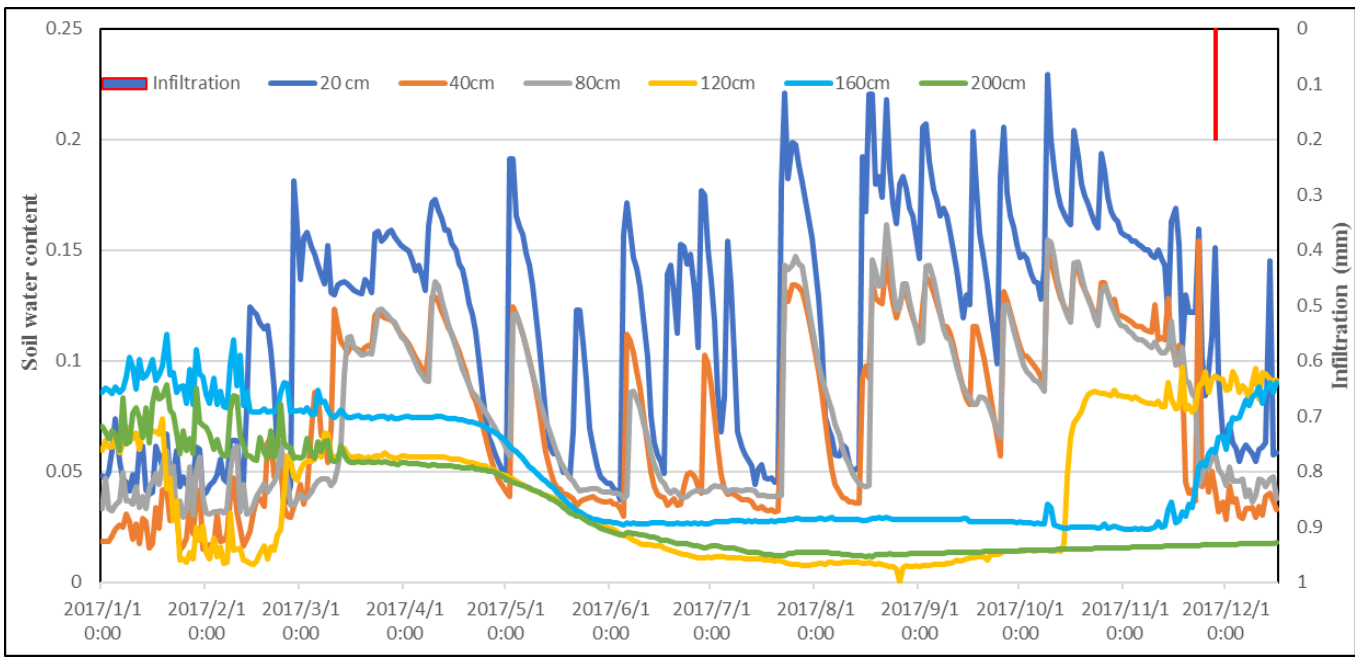

Figure 5 Soil moisture and DSR dynamic change in 2017

The total precipitation mount in 2018 is $472.2 \mathrm{~mm}$, which is a wet year. There are 42 observed precipitation events throughout the year with a maximum precipitation intensity of $20 \mathrm{~mm} / \mathrm{d}$ on $21 \mathrm{July}, 2017$. The soil moisture fluctuation in 2018 is similar to that in 2016 and 2017. There is a freezing period in January-March, in which the soil water content changes in each layer are relatively stable. The March and April belong to the freezing and thawing period, the frozen soil water gradually melts, and soil below the surface layer is replenished by the melted water. Consequently, the soil moistures in various layers rise accordingly. From April to November, it belongs to the active season of the rainy season. Under the combined action of precipitation recharge, soil evapotranspiration and vegetation consumption, the soil moisture fluctuates. The shallow soil layer begins to freeze again in December.

As shown in Figure 6, the layers of strong soil moisture fluctuations are $20 \mathrm{~cm}, 40 \mathrm{~cm}, 80 \mathrm{~cm}, 120 \mathrm{~cm}$, and 160 $\mathrm{cm}$. The $200 \mathrm{~cm}$ level of soil changes relatively small, and was only recharged on September $7^{\text {th }}$ of 2018 . The annual soil moisture infiltration is only $1.2 \mathrm{~mm}$ in 2018, which is $1 \mathrm{~mm}$ higher than that in 2017 and $0.2 \mathrm{~mm}$ lower than that in 2016 . 


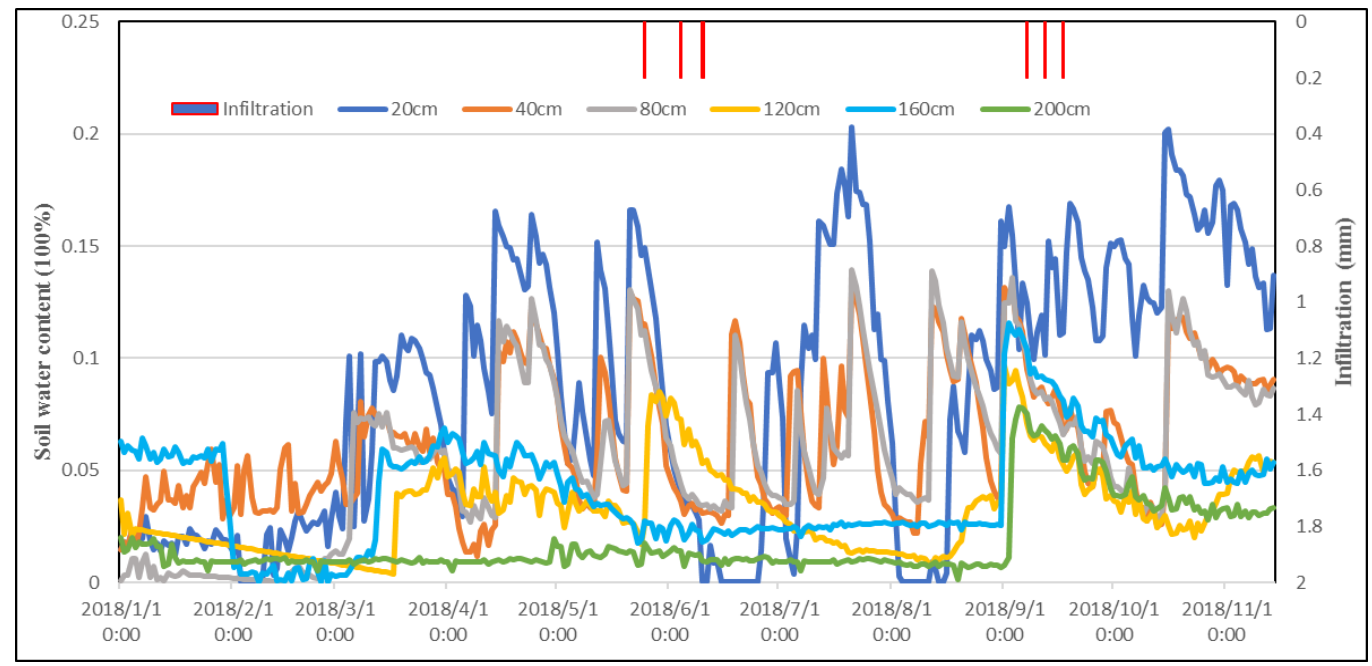

Figure 6. Soil moisture and DSR dynamic change in 2018.

\subsection{Soil moisture infiltration rate comparison during different seasons}

The soil moisture recharge sources in the experimental area are spring snowmelt and summer precipitation. According to Figure 3, we can clearly see that the soil water recharge in different seasons varies, especially at the end of winter season and in the summer rainy season. The amount of spring precipitation in this study site is small, and snowmelt moisture is the main water source in this semi-arid area. The germination process of vegetation or seeds in semi-arid areas mainly depends on the water source of accumulated snowfall in winter. With the surface soil temperature increasing, the surface ice water gradually melts and infiltrates to deeper soil layer. As shown in Figure $7(\mathrm{AB})$, this study chooses two typical processes for comparison: the snow melted soil moisture recharge process from February $26^{\text {th }}$ to March $27^{\text {th }}$ of 2016 , and the precipitation recharge process from July $3^{\text {rd }}$ to $12^{\text {th }}$ of 2016 . During the process of snowmelt infiltration, the soil wetting front moves slowly downward in the vertical direction, as shown in Figure 5A, it takes 2 days and 7 hours for the wetting point reaching the $60 \mathrm{~cm}$ soil layer, but for summer precipitation infiltration process, it takes only 1 day for wetting front to reach $60 \mathrm{~cm}$ soil layer.

The February $26^{\text {th }}$ to March $27^{\text {th }}$ of 2016 snow melted soil moisture recharge process lasts for 29 days, and the soil moisture recharge depth reaches $160 \mathrm{~cm}$. The soil moisture at $200 \mathrm{~cm}$ depth does not show any noticeable change, suggesting that DSR has not been generated. The start time of moisture recharge is set at when soil moisture content starts to increase. The end time of moisture recharge is set at when soil moisture content reaches its maximum. These two moisture infiltration processes are shown in Figure 7. There are many factors affecting the rate of precipitation infiltration. A model that does not adequately consider the most relevant factors can certainly leads to erroneous simulation results. In the future, the gap between the experimental measurement results and the corresponding model simulation results much be investigated and eventually filled. 

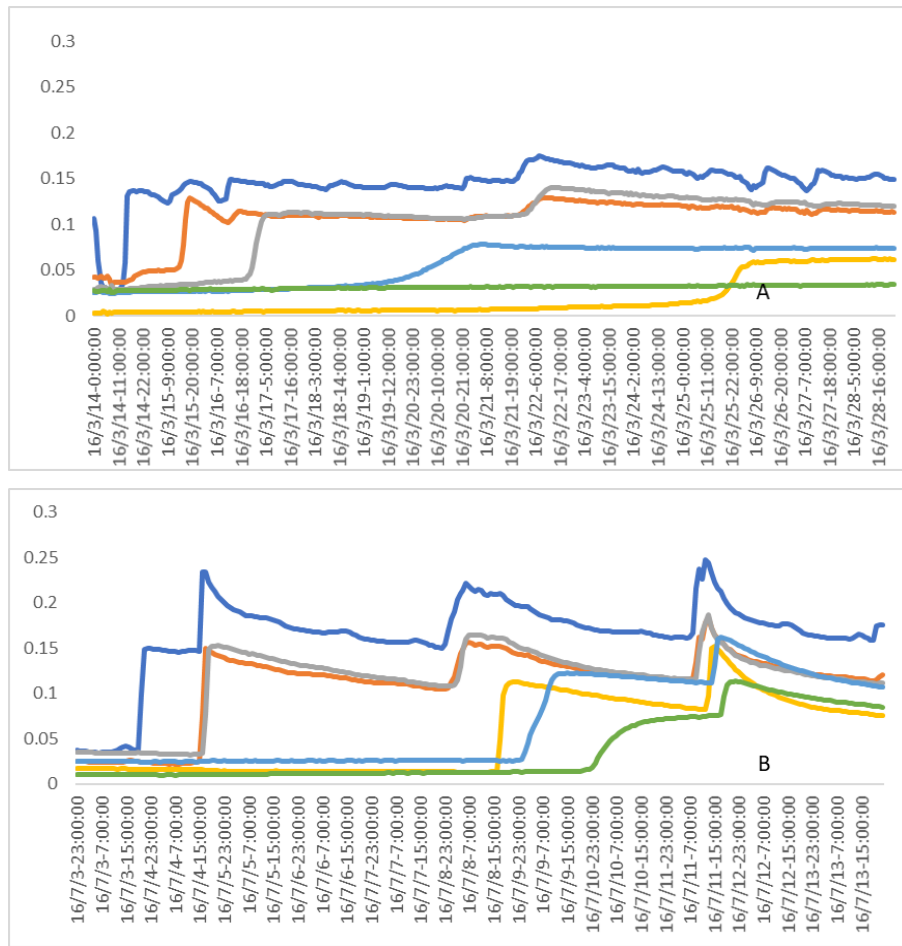

Figure 7. Two recharge process (snow melt process and precipitation process) in 2016.

\subsection{Recharge intensity of different soil layer infiltration}

In the laboratory, one may calculate the precipitation intensity infiltrating into a specific soil layer according to the soil characteristics with a proper mathematical model. In the natural environment, however, there are too many factors affecting the infiltration process, such as temperature and air humidity, wind speed, surface soil moisture, soil heterogeneity, etc. In this study, we computed the replenishment of each soil layer by analyzing the precipitationinduced wetting point to find out the minimum precipitation intensity for each individual layer.

Precipitation infiltration results in increasing soil moisture content. Each time when soil moisture infiltrates into a designated depth, it leaves a crest signal. Based on the comparison between the number of crest signals and the number of precipitations, the minimum precipitation amount can be determined by the crest signals at different soil depths. Statistics of precipitation data from 2016 to 2018 and fluctuations in soil moisture content in each layer are shown in Table 1, which shows that when precipitation infiltrates to soil layers at $20 \mathrm{~cm}, 40 \mathrm{~cm}, 80 \mathrm{~cm}, 120 \mathrm{~cm}, 160$ $\mathrm{cm}$, and $200 \mathrm{~cm}$ depths, the minimum precipitation intensities are $2.6 \mathrm{~mm} / \mathrm{d}, 3.2 \mathrm{~mm} / \mathrm{d}, 3.4 \mathrm{~mm} / \mathrm{d}, 8.2 \mathrm{~mm} / \mathrm{d}, 8.2 \mathrm{~mm} / \mathrm{d}$, and $13.2 \mathrm{~mm} / \mathrm{d}$, respectively. When heavy precipitation events (precipitation intensity higher than $100 \mathrm{~mm} / \mathrm{d}$ ) happen in the study site, precipitation can recharge the soil moisture at $200 \mathrm{~cm}$ depth. 
Table 1 Precipitation produced moisture increase signal and corresponding minimum precipitation intensity (data from 2016-2018).

\begin{tabular}{ccc}
\hline Soil layer depths & $\begin{array}{c}\text { Sum of soil moisture increase signals } \\
\text { on each soil layer }\end{array}$ & $\begin{array}{c}\text { Corresponding minimum } \\
\text { precipitation intensity }\end{array}$ \\
\hline $20 \mathrm{~cm}$ & 74 & $2.6 \mathrm{~mm} / \mathrm{d}$ \\
$40 \mathrm{~cm}$ & 46 & $3.2 \mathrm{~mm} / \mathrm{d}$ \\
$80 \mathrm{~cm}$ & 32 & $3.4 \mathrm{~mm} / \mathrm{d}$ \\
$120 \mathrm{~cm}$ & 16 & $8.2 \mathrm{~mm} / \mathrm{d}$ \\
$160 \mathrm{~cm}$ & 16 & $10.2 \mathrm{~mm} / \mathrm{d}$ \\
$200 \mathrm{~cm}$ & 10 & $13.2 \mathrm{~mm} / \mathrm{d}$ \\
\hline
\end{tabular}

Figure 3 shows that during the seasonal frozen-soil period, soil moisture is relatively stable. The monthly average values for soil moistures of different soil layers in January and December of 2016 are used as the start and end soil moisture values. Although the precipitation amount varies from 2016 to 2018, other environmental factors in this area are basically the same, and soil moistures are similar. To figure out the Pinus sylvestris var. mongolica water balance from 2016 to 2018 , one has:

$$
\mathrm{P}-\mathrm{DSR}-\mathrm{ET}=\delta \mathrm{W}
$$

where $\mathrm{P}$ is precipitation, ET is evapotranspiration, and $\delta \mathrm{W}$ is the whole $200 \mathrm{~cm}$ soil layer moisture change. Runoff is not included in above water balance equation because it does not occur during the experiment. As P, DSR, and $\delta \mathrm{W}$ can be accurately measured, ET can be calculated by above equation.

Table 2 Water distribution in 2016 of the rain-feed Pinus sylvestris var.

\begin{tabular}{c|cccc}
\hline Year & Precipitation & DSR & $\delta \mathrm{W}$ & ET \\
\hline 2016 & $466.4 \mathrm{~mm}$ & $1.4 \mathrm{~mm}$ & $38.056 \mathrm{~mm}$ & $426.96 \mathrm{~mm}$ \\
\hline 2017 & $309 \mathrm{~mm}$ & $0.4 \mathrm{~mm}$ & $-16 \mathrm{~mm}$ & $324.6 \mathrm{~mm}$ \\
\hline 2018 & $472.2 \mathrm{~mm}$ & $1.2 \mathrm{~mm}$ & $54.747 \mathrm{~mm}$ & $416.253 \mathrm{~mm}$ \\
\hline
\end{tabular}

As shown in Table 2, precipitation in the experimental area in 2016 is $466.4 \mathrm{~mm}$ and the DSR is $1.4 \mathrm{~mm}$. Thanks to the heavy precipitation in the summer and the higher than multi-year average precipitation (multi-year average precipitation is $400 \mathrm{~mm}$ ), all soil layer moisture content $(\delta \mathrm{W})$ increases $38.056 \mathrm{~mm}$ within the upper $200 \mathrm{~mm}$ depth. The groundwater table is $8 \mathrm{~m}$ depth, beyond the root range of Pinus sylvestris var. mongolica. Therefore, Pinus 
and soil moisture content change, the evapotranspiration of Pinus sylvestris var. mongolica can be calculated as 426.96 $\mathrm{mm} /$ year. 2017 is a dry year with a precipitation of $309 \mathrm{~mm}$, DSR of $0.4 \mathrm{~mm}$, soil water storage decreased by $16 \mathrm{~mm}$, evapotranspiration mount is $324.6 \mathrm{~mm}$. The precipitation mount in 2018 is $472.2 \mathrm{~mm}$. The DSR is $1.2 \mathrm{~mm}$, the soil water storage capacity is increased by $54.747 \mathrm{~mm}$, and the evapotranspiration is $416.253 \mathrm{~mm}$. Based on the redistribution data of precipitation in the shallow soil (200 cm depth) over the past three years, one can see that precipitation has a recharge effect on both shallow and deep soil layers. In the shallow soil layer, evapotranspiration in the dry year consumes stored water, but in the wet year precipitation water recharge the shallow soil layer. Deep soil layer infiltration has been recorded in the past three years with very small amount, indicating that under the existing vegetation cover and rain-fed conditions, the precipitation is barely able to support the shallow ecosystems, and only a small amount of precipitation can percolate into the deep soil layer.

Comparing the data of three years in Table 2, DSR of the experiment site is relatively small, indicating that the soil moisture resource in the Pinus sylvestris var. mongolica forest is limited under this rain-fed conditions. In the dry years, the soil evaporation was relative large, but the measured total evapotranspiration decreased, indicating that the transpiration of vegetation was inhibited. Under this condition, Pinus sylvestris var. cannot grow well. In semiarid regions, precipitation varies considerably every year, and the year of 2016 may not be representative of the long-term average behavior of DSR in this region as the precipitation of this year is higher than the average annual precipitation of $400 \mathrm{~mm}$. Instead, it may be more representative of a wet year behavior, so as 2017 and 2018 . To figure out the long-term behavior of DSR and SWC in the semiarid regions such as Mu Us Sandy land, one must carry out a multiyear (preferably a decade long) experiment.

\section{Summary and Conclusions}

As one of the four largest artificial shelter forest system, three North shelter forest system project which includes the Mu Us Sandy land investigated here, has a history of nearly 40 years of construction. On one hand, artificial shelter forest prevents the invasion of desert; on the other hand, construction of a vast artificial shelter forest may have detrimental effect on ecological environment in arid regions and may substantially change the evapotranspiration pattern in the region. Since precipitation is almost the only water sources for replenishing the groundwater system in the Mu Us Sandy land, change of evapotranspiration will greatly affect the groundwater recharge in the region, which directly determines if the reforestation can be sustainable. This study uses a 30-years-old mature Pinus sylvestris var. mongolica forest of a 10-meter line spacing as the target of the experiment. The study uses a new lysimeter to monitor DSR and to accurately calculate water balance from 2016 to 2018. The following conclusions can be drawn from this study:

1. Pinus sylvestris var. mongolica forest soil in Mu Us Sandy land has two significant moisture recharge processes in an annual base: spring snow melted moisture infiltration-recharge process and summer precipitation-recharge process. The recharge depth of spring snow melted moisture recharge process is $160 \mathrm{~cm}$. The summer precipitation-recharge process results in DSR, recharging the soil moisture below $200 \mathrm{~cm}$. The DSR of 20162018 is $1.4 \mathrm{~mm}, 0.2 \mathrm{~mm}, 1.2 \mathrm{~mm}$, respectively. Under the existing precipitation conditions, water supply in the 
rain-fed pine forest can meet the consumption of vegetations but the remaining amount of rain-fed infiltration that can percolate into deep soil layer is small.

2. The experimental results show that the precipitation intensities are respectively $2.6 \mathrm{~mm} / \mathrm{d}, 3.2 \mathrm{~mm} / \mathrm{d}, 3.4 \mathrm{~mm} / \mathrm{d}$, $8.2 \mathrm{~mm} / \mathrm{d}, 8.2 \mathrm{~mm} / \mathrm{d}$, and $13.2 \mathrm{~mm} / \mathrm{d}$ when precipitation infiltrates into $20 \mathrm{~cm}, 40 \mathrm{~cm}, 80 \mathrm{~cm}, 120 \mathrm{~cm}, 160 \mathrm{~cm}$, and $200 \mathrm{~cm}$ soil depths. Infiltration depth and precipitation intensity are not linearly related.

3. In semi-arid areas, the annual precipitation varies greatly, the dry and wet years alternate, DSR mount is relatively small, soil water mount is limited. The growth of Pinus is affected by annual precipitation. Compared to the start of the year, soil moisture content increases $38.056 \mathrm{~mm},-16 \mathrm{~mm}, 54.747 \mathrm{~mm}$.

4. The precipitations in 2016-2018 are $466.4 \mathrm{~mm}, 309 \mathrm{~mm}, 472.2 \mathrm{~mm}$, and the associated DSR values are $1.4 \mathrm{~mm}$, $0.2 \mathrm{~mm}, 1.2 \mathrm{~mm}$, respectively. Under the current precipitation condition and reforestation design, the natural recharging moisture of Pinus sylvestris var. mongolica can meet the plant growth needs, and have additional moisture for DSR which may eventually recharge groundwater.

5. Calculation based on these dataset shows that the annual evaporation of Pinus sylvestris var. mongolica forest in Mu Us sandy land is $426.96 \mathrm{~mm}, 324.6 \mathrm{~mm}, 416.253 \mathrm{~mm}$ for year 2016-2018, respectively. Pinus automatically adjusts its evapotranspiration in response to different precipitation amount, and this may affect the development of Pinus sylvestris var. As extreme weather conditions happen more frequently worldwide (possibly due to the global warming effect), the arid region precipitation may change rapidly. Whether Pinus sylvestris var. mongolica can adapt to this trend is a question that still needs decades-long observational effort.

\section{Acknowledgements:}

This study was supported with research grants from the Fundamental Research Funds for the Central Universities (BLX201814) and the National Natural Science Foundation of China (41771306). I especially thanks Chinese Scholar Council support me to go to Texas A\&M University as a visiting researcher.

\section{References}

Bao, G.: Mongolian pines (Pinus sylvestris var. mongolica) in the Hulun Buir steppe, China, respond to climate in adjustment to the local water supply, International Journal of Biometeorology, 59, 1-10, 10.1007/s00484-0130767-3, 2015

Barton, L., Kiese, R., Gatter, D., Butterbach-Bahl, K., Buck, R., Hinz, C., and Murphy, D. V.: Nitrous oxide emissions from a cropped soil in a semi-arid climate, Global Change Biology, 14, 177-192, 10.1111/j.13652486.2007.01474.x, 2008.

Bawa, K. S., Koh, L. P., Lee, T. M., Liu, J., Ramakrishnan, P., Douglas, W. Y., Zhang, Y.-p., and Raven, P. H.: China, India, and the environment, Science, 327, 1457-1459, 2010.

Boserup, E.: The conditions of agricultural growth: The economics of agrarin change under population pressure, Transaction Publishers, 2011. 
Bouwman, A., Van der Hoek, K., Eickhout, B., and Soenario, I.: Exploring changes in world ruminant production systems, Agricultural Systems, 84, 121-153, 2005, doi.org/10.1016/j.agsy.2004.05.006.

Cao, S., Chen, L., Shankman, D., Wang, C., Wang, X., and Zhang, H.: Excessive reliance on afforestation in China's arid and semi-arid regions: lessons in ecological restoration, Earth-Science Reviews, 104, 240-245, 2011, doi.org/10.1016/j.earscirev.2010.11.002.

Cheng, Y., Zhan, H., Yang, W., Dang, H., and Li, W.: Is annual recharge coefficient a valid concept in arid and semi-arid regions?, Hydrol. Earth Syst. Sci., 21, 5031-5042, 10.5194/hess-21-5031-2017, 2017.

Contreras, S., Jobbágy, E. G., Villagra, P. E., Nosetto, M. D., and Puigdefábregas, J.: Remote sensing estimates of supplementary water consumption by arid ecosystems of central Argentina, Journal of Hydrology, 397, 10-22, https://doi.org/10.1016/j.jhydrol.2010.11.014, 2011.

Fagg, C. W., and Stewart, J. L.: The value of Acacia and Prosopis in arid and semi-arid environments, Journal of Arid Environments, 27, 3-25, https://doi.org/10.1006/jare.1994.1041, 1994.

Gao, Y., Zhu, X., Yu, G., He, N., Wang, Q., and Tian, J.: Water use efficiency threshold for terrestrial ecosystem carbon sequestration in China under afforestation, Agricultural and Forest Meteorology, 195-196, 32-37, https://doi.org/10.1016/j.agrformet.2014.04.010, 2014.

García Chevesich, P., Neary, D. G., Scott, D. F., Benyon, R. G., and Reyna, T.: Forest management and the impact on water resources: a review of 13 countries, UNESCO Publishing, 2017.

Gerten, D., Schaphoff, S., Haberlandt, U., Lucht, W., and Sitch, S.: Terrestrial vegetation and water balancehydrological evaluation of a dynamic global vegetation model, Journal of Hydrology, 286, 249-270, https://doi.org/10.1016/j.jhydrol.2003.09.029, 2004.

Gong, D.-Y., Shi, P.-J., and Wang, J.-A.: Daily precipitation changes in the semi-arid region over northern China, Journal of Arid Environments, 59, 771-784, https://doi.org/10.1016/j.jaridenv.2004.02.006, 2004.

Hu, Y. L., Zeng, D. H., Fan, Z. P., Chen, G. S., Zhao, Q., and Pepper, D.: Changes in ecosystem carbon stocks following grassland afforestation of semiarid sandy soil in the southeastern Keerqin Sandy Lands, China, Journal of Arid Environments, 72, 2193-2200, https://doi.org/10.1016/j.jaridenv.2008.07.007, 2008.

Jiao, J., Zhang, Z., Bai, W., Jia, Y., and Wang, N.: Assessing the Ecological Success of Restoration by Afforestation on the Chinese Loess Plateau, Restoration Ecology, 20, 240-249, 10.1111/j.1526-100X.2010.00756.x, 2012.

Kraemer, R., Prishchepov, A. V., Müller, D., Kuemmerle, T., Radeloff, V. C., Dara, A., Terekhov, A., and Frühauf, M.: Long-term agricultural land-cover change and potential for cropland expansion in the former Virgin Lands area of Kazakhstan, Environmental Research Letters, 10, 054012, 2015.

Li, W., Yan, M., Qingfeng, Z., and Xingchang, Z.: Groundwater use by plants in a semi-arid coal-mining area at the Mu Us Desert frontier, Environmental Earth Sciences, 69, 1015-1024, 10.1007/s12665-012-2023-2, $2013 \mathrm{a}$.

Li, X.-R., Xiao, H.-L., Zhang, J.-G., and Wang, X.-P.: Long-Term Ecosystem Effects of Sand-Binding Vegetation in the Tengger Desert, Northern China, Restoration Ecology, 12, 376-390, 10.1111/j.1061-2971.2004.00313.x, 2004. 
Li, X., Zhang, Z., Huang, L., and Wang, X.: Review of the ecohydrological processes and feedback mechanisms controlling sand-binding vegetation systems in sandy desert regions of China, Chinese Science Bulletin, 58, 1483-1496, 10.1007/s11434-012-5662-5, 2013b.

Ma, Z., Kang, S., Zhang, L., Tong, L., and Su, X.: Analysis of impacts of climate variability and human activity on streamflow for a river basin in arid region of northwest China, Journal of Hydrology, 352, 239-249, https://doi.org/10.1016/j.jhydrol.2007.12.022, 2008.

Menon, S., Hansen, J., Nazarenko, L., and Luo, Y.: Climate effects of black carbon aerosols in China and India, Science, 297, 2250-2253, 2002, DOI: 10.1126/science.1075159.

Ngigi, S. N., Savenije, H. H. G., Rockström, J., and Gachene, C. K.: Hydro-economic evaluation of rainwater harvesting and management technologies: Farmers' investment options and risks in semi-arid Laikipia district of Kenya, Physics and Chemistry of the Earth, Parts A/B/C, 30, 772-782, https://doi.org/10.1016/j.pce.2005.08.020, 2005.

Powell, J. W., Gilbert, G. K., Dutton, C. E., Drummond, W., and Thompson, A. H.: Report on the Lands of the Arid Region of the United States: With a More Detailed Account of the Lands of Utah. With Maps, Governmentprint. Office, 1879.

Rhee, J., Im, J., and Carbone, G. J.: Monitoring agricultural drought for arid and humid regions using multi-sensor remote sensing data, Remote Sensing of Environment, 114, 2875-2887, https://doi.org/10.1016/j.rse.2010.07.005, 2010.

Roth, B. E., Slatton, K. C., and Cohen, M. J.: On the potential for high-resolution lidar to improve precipitation interception estimates in forest ecosystems, Frontiers in Ecology and the Environment, 5, 421-428, 10.1890/060119.1, 2007.

Runnström, M. C.: Is Northern China Winning the Battle against Desertification?, AMBIO: A Journal of the Human Environment, 29, 468-476, 10.1579/0044-7447-29.8.468, 2000.

Runnström, M. C.: Rangeland development of the Mu Us Sandy Land in semiarid China: an analysis using Landsat and NOAA remote sensing data, Land Degradation \& Development, 14, 189-202, 10.1002/ldr.545, 2003.

Sharma, P., and Sharma, P.: Ecology and environment, Rastogi Publications, 2005.

Su, Y. Z., Zhao, W. Z., Su, P. X., Zhang, Z. H., Wang, T., and Ram, R.: Ecological effects of desertification control and desertified land reclamation in an oasis-desert ecotone in an arid region: a case study in Hexi Corridor, northwest China, Ecological Engineering, 29, 117-124, 2007, doi.org/10.1016/j.ecoleng.2005.10.015.

Sun, W., Song, X., Mu, X., Gao, P., Wang, F., and Zhao, G.: Spatiotemporal vegetation cover variations associated with climate change and ecological restoration in the Loess Plateau, Agricultural and Forest Meteorology, 209, 87-99, 2015, doi.org/10.1016/j.agrformet.2015.05.002.

Wang, F., Pan, X., Wang, D., Shen, C., and Lu, Q.: Combating desertification in China: past, present and future, Land Use Policy, 31, 311-313, 2013, doi.org/10.1016/j.landusepol.2012.07.010.

Wang, T., Zhu, Z., and Wu, W.: Sandy desertification in the north of China, Science in China Series D: Earth Sciences, 45, 23-34, 10.1007/bf02878385, 2002. 
Hydrol. Earth Syst. Sci. Discuss., https://doi.org/10.5194/hess-2019-110

Manuscript under review for journal Hydrol. Earth Syst. Sci.

Discussion started: 18 March 2019

(c) Author(s) 2019. CC BY 4.0 License.

(c) (1)

Wang, T., Wu, W., Xue, X., Han, Z., Zhang, W., and Sun, Q.: Spatial-temporal changes of sandy desertified land during last 5 decades in northern China, ACTA GEOGRAPHICA SINICA-CHINESE EDITION-, 59, 203-212, 2004.

Wang, X., Zhang, C., Hasi, E., and Dong, Z.: Has the Three Norths Forest Shelterbelt Program solved the desertification and dust storm problems in arid and semiarid China?, Journal of Arid Environments, 74, 13-22, 2010a, doi.org/10.1016/j.jaridenv.2009.08.001.

Wang, X. M., Zhang, C. X., Hasi, E., and Dong, Z. B.: Has the Three Norths Forest Shelterbelt Program solved the desertification and dust storm problems in arid and semiarid China?, Journal of Arid Environments, 74, 13-22, https://doi.org/10.1016/j.jaridenv.2009.08.001, 2010b.

Wenhua, L.: Degradation and restoration of forest ecosystems in China, Forest Ecology and Management, 201, 33 41, https://doi.org/10.1016/j.foreco.2004.06.010, 2004.

Wu, Z., Wu, J., Liu, J., He, B., Lei, T., and Wang, Q.: Increasing terrestrial vegetation activity of ecological restoration program in the Beijing-Tianjin Sand Source Region of China, Ecological Engineering, 52, 37-50, 2013, doi.org/10.1016/j.ecoleng.2012.12.040.

Yang, X., Zhang, K., Jia, B., and Ci, L.: Desertification assessment in China: An overview, Journal of Arid

430 Environments, 63, 517-531, 2005, doi.org/10.1016/j.jaridenv.2005.03.032.

Young, A.: Agroforestry for soil conservation, 04; S599. 9. T76, Y68., CAB international Wallingford, UK, 1989.

Zhu, J., Kang, H., Tan, H., and Xu, M.: Effects of drought stresses induced by polyethylene glycol on germination of Pinus sylvestris var. mongolica seeds from natural and plantation forests on sandy land, Journal of Forest Research, 11, 319-328, 2006, doi.org/10.1007/s10310-006-0214-y.

435 